\begin{tabular}{ll}
\hline \hline INSTITUT ZA RUDARSTVO I METALURGIJU BOR & YU ISSN: 1451-0162 \\
KOMITET ZA PODZEMNU EKSPLOATACIJU MINERALNIH SIROVINA & UDK: 622 \\
\hline \hline
\end{tabular}

UDK: $621 \cdot 967 \cdot 2: 622 \cdot 27 \cdot 1: 622.7(045)=861$

Bojan Drobnjaković, Dragan Milanović, Vesna Drobnjaković

\begin{abstract}
IZBOR POGONSKE GRUPE TRAKASTOG DODAVAČA DROBILIČNOG POSTROJENJA ZA RUDU/JALOVINU NA POVRŠINSKOM KOPU RUDNIKA VELIKI KRIVELJ**
\end{abstract}

Izvod

Izgradnjom primarnog drobiličnog postrojenja br.2 u okviru površinskog kopa rudnika Veliki Krivelj postiže se veći kapacitet prerade rude bakra u cilju povećanja kapaciteta rudnika bakra

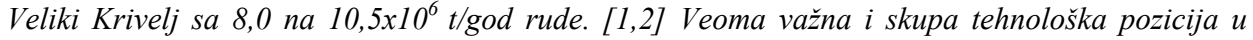
okviru postrojenja je trakasti dodavač ispod primarne drobilice tipa kružno-konusna Allis Chalmers 48"x74" kojim se doprema ruda dalje na transportni sistem za rudu ili na transportni sistem za jalovinu, ukoliko se vrši drobljenje jalovine. Sa povećanjem kapaciteta prerade rude/jalovine rudnika bakra Veliki Krivelj povećava se i količina raskrivke/rude istoimenog površinskog kopa a posledično i količina produkovane topioničke šljake iz procesa topljenja koncentrata bakra dobijenog iz flotacija Veliki Krivelj, Bor i Majdanpek.

Ključne reči: transportni sistem, ruda/jalovina, trakastidodavač, pogonska grupa

\section{UVOD}

Prema usvojenim strateškim planovima razvoja RTB - Bor potrebno je bilo izvršiti izgradnju drobiličnog postrojenja br. $2 \mathrm{u}$ okviru transportnog sistema za jalovinu od površinskog kopa rudnika Veliki Krivelj do odkopanog prostora površinskog kopa Bor. Dodatnim sagledavanjima došlo se od ideje da se ovo drobilično postrojenje iskoristi i za drobljenje rude a, ne samo za drobljenje jalovine kao što je slučaj sa postojećim drobiličnim postrojenjem br. 1. Sastavni delovi drobiličnog postrojenja su: prijemni bunker za rudu/jalovinu, člankasti dodavač, prihvatni bunker drobilice, kružno-konusna primarna drobilica, izlazni levak drobilice, trakasti dodavač ispod drobilice, pretovarna sipka, reverzibilni dodavač, izlazna sipka za rudu i izlazna sipka za jalovinu.

Sastavni deo drobiličnog postrojenja je trakasti transporter - dodavač, koji se nalazi

\footnotetext{
* Institut za rudarstvo i metalurgiju Bor

** Ovaj rad je proistekao kao rezultat projekta evidencioni broj TR 33023 „, Razvoj tehnologija flotacijske prerade ruda bakra i plemenitih metala radi postizanja boljih tehnoloških rezultat " finasiranog od strane Ministarstva prosvete i nauke Republike Srbije.
} 
ispod drobilice i doprema material na reverzibilni transportet $\mathrm{i}$ dalje na transporter za rudu, odnosno transporter za jalovinu. Postavljen je pod uglom od 5,50.

Investitor je doneo odluku da za ovu namenu iskoristi postojeći trakasti dodavač iz rudnika Majdanpek, sa tzv. faze IV koji više godina nije u radu. Na slici br.1 data je tehnološka šema sa pozicijama sastavnih delova instalisanog drobiličnog postrojenja br. 2, dok je na slici br. 2 prikazano izgrađeno drobilično postrojenje br. 2, a na slikama br. 3 i br. 4 su prikazane faze ugradnje pogonske grupe trakastog dodavača.

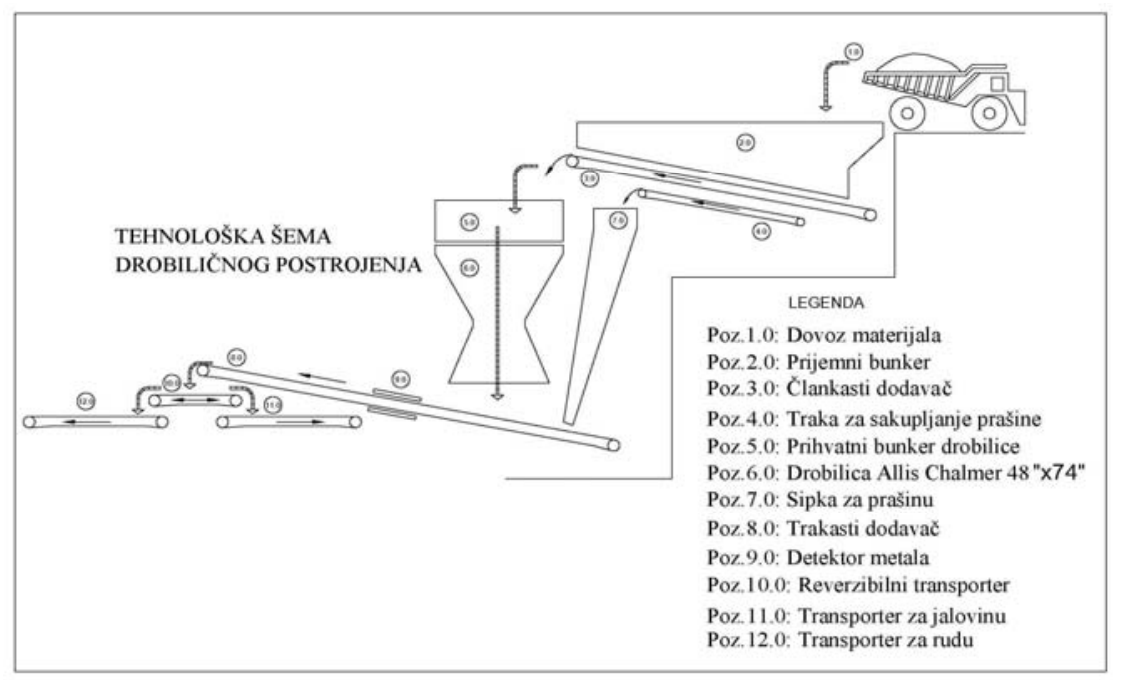

S1. 1. Tehnološka šema instalisanog drobiličnog postrojenja br.2.

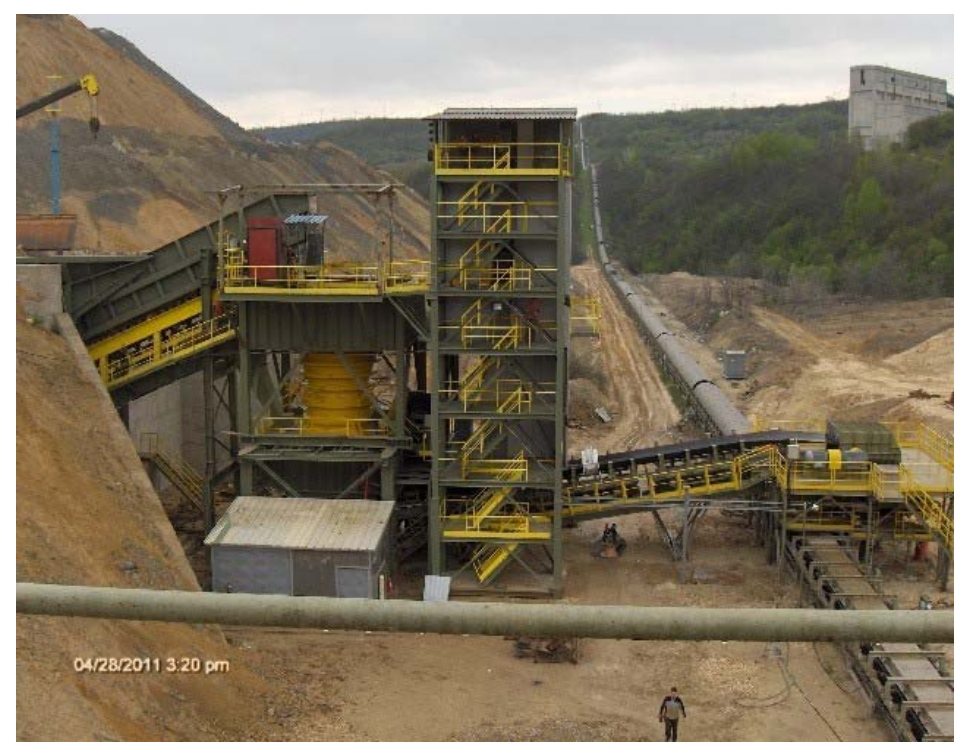

Sl. 2. Vizuelni prikaz instalisanog drobiličnog postrojenja br.2. 


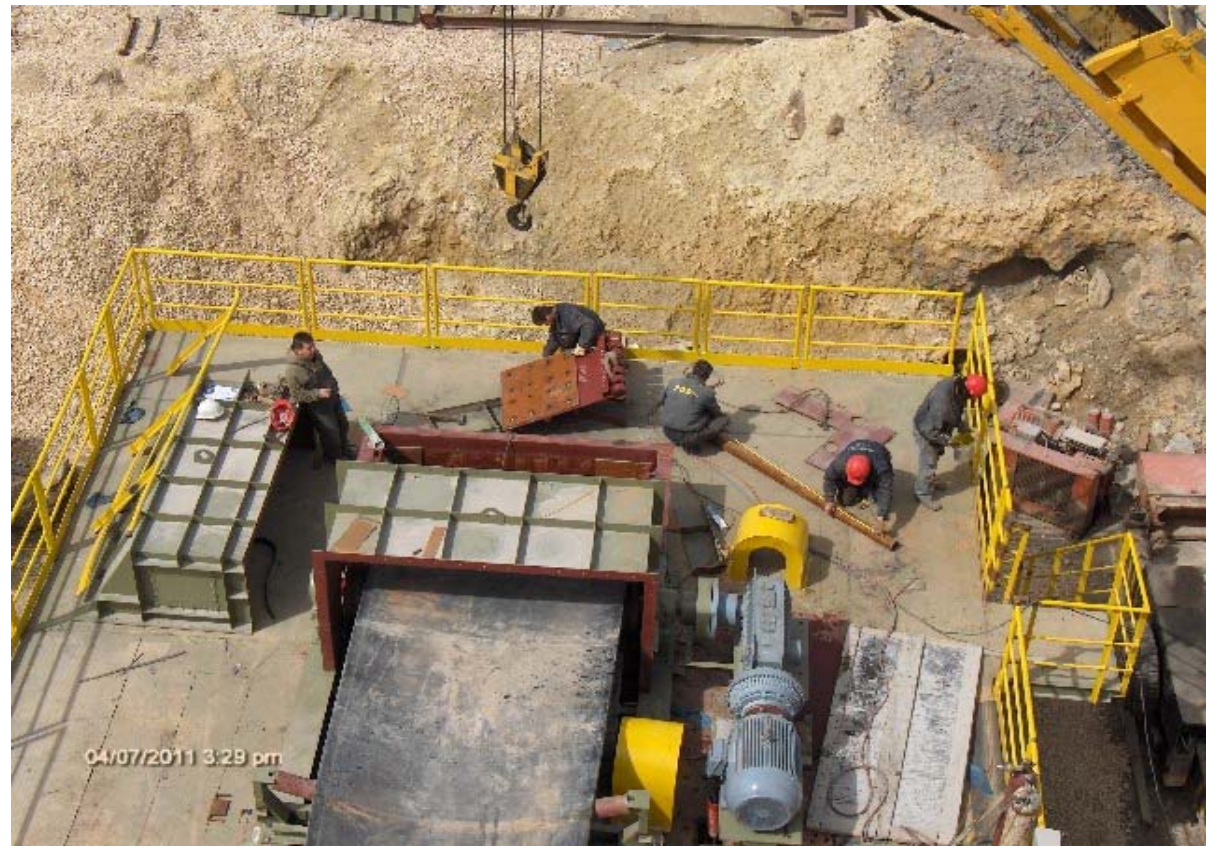

SI. 3 Instalacija pogonske grupe trakastog dodavača poz. T-103.

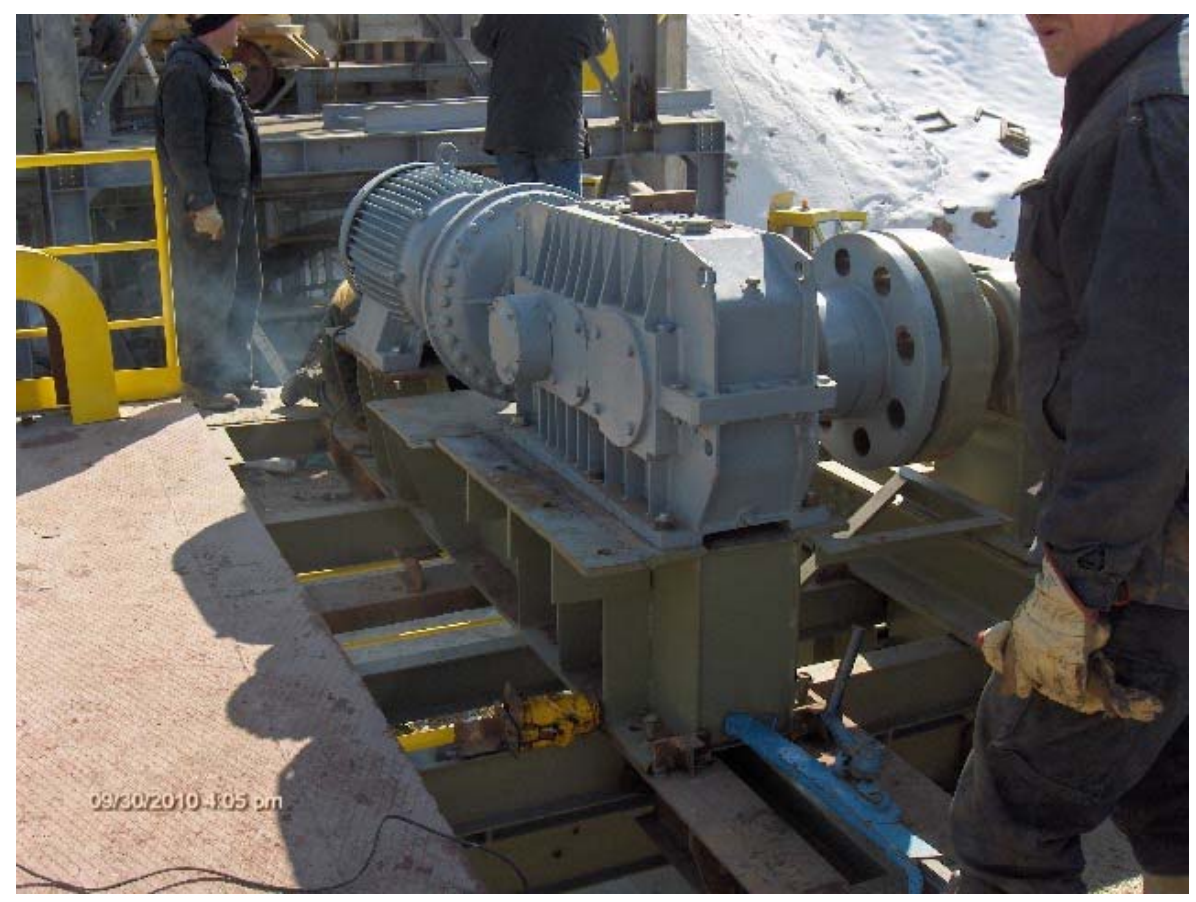

SI. 4. Prikaz pogonske grupe. Elektromotor reduktor spojnica. 


\section{PRORAČUN POGONSKE GRUPE TRANSPORTERA T-103}

Potrebno je sprovesti analizu instalisanog kapaciteta transportera na poz. T103, samim tim i proveru pogonske snage elektromotora tog transportera s obzirom da se visina dizanja transportovanog materijala povećava za $1,5 \mathrm{~m}$, što nije zanemarljivo. [3,4]

$\mathrm{S}$ obzirom na to, očekivanja su da pogonska snaga elektromotora bude na samoj granici zadovoljavanja pogonskih uslova. Količina transportovanog materijala je ista, kako na poziciji u rudniku Majdanpek tako i na ovoj poziciji $u$ rudniku Veliki Krivelj.

Proračun ovog trakastog transportera može da se vrši na osnovu standarda SRPS M.D2.050, s obzirom da je transporter male dužine.

Proračun kapaciteta stacionarnog transportera podrazumeva verifikaciju kapaciteta trakastog transportera - dodavača ispod primarne drobilice, tehnološke pozicije T-103, u dužini od $25 \mathrm{~m}$ i visine dizanja $4,15 \mathrm{~m}$ pri brzini gumene transportne trake od $2,43 \mathrm{~m} / \mathrm{s}$.

\section{Izbor širine trake}

Širina trake je određena ne kapacitetom već izlaznim otvorom drobilice. Širina gumene trake je $2200 \mathrm{~mm}$, i ona zadovoljova u svakom pogledu.

Provera preseka nasipa trake prema količini transportovanog materijala

Presek nasipa trake se izračunava prema obrascu:

$$
A=\frac{1}{k_{1} \cdot k_{2}} \cdot \frac{Q}{3600 \cdot \rho \cdot v}
$$

gde je:

A - površina preseka nasipa, $\mathrm{u}^{2}$

Q - količina (masa) transportovanog materijala, u t/h, $\rho$ - zapreminska masa (gustina) transportovanog materijala $\mathrm{u} \mathrm{kg} / \mathrm{m}^{3}$,

$\mathrm{v}$ - brzina trake, $\mathrm{m} / \mathrm{s}$,

$\mathrm{k}_{1}$-koeficijent smanjenja teorijskog kapaciteta, zbog neravnomernog i nepotpunog nasipanja,

$\mathrm{k}_{2}$-koeficijent smanjenja teorijskog kapaciteta, zbog nagiba transportera.

Tabela. 1

\begin{tabular}{|c|r|}
\hline Parametar & \multicolumn{1}{|c|}{ T 103 B } \\
\hline $\mathrm{Q}$ & $2350 \mathrm{t} / \mathrm{h}$ \\
\hline$\rho$ & $1600 \mathrm{~kg} / \mathrm{m}^{3}$ \\
\hline $\mathrm{k}_{1}$ & 0,95 \\
\hline $\mathrm{k}_{2}$ & 0,95 \\
\hline $\mathrm{v}$ & $2,1 \mathrm{~m} / \mathrm{s}$ \\
\hline $\mathrm{A}$ & $0,215 \mathrm{~m}^{2}$ \\
\hline
\end{tabular}

- Aktivna širina trake:

$$
b_{1}=\sqrt{\frac{A \cdot 3600}{f}}=1,2 \mathrm{~m}
$$

gde je:

$\mathrm{b}_{1}$ - aktivna širina trake, $\mathrm{u} \mathrm{m}$

f - factor oblika preseka nasipa. Za koritasti oblik, sa bočnim uglovima od $35^{\circ}$, faktor ima vrednost, $\mathrm{f}=550$.

Aktivna širina trake je $1,5 \mathrm{~m}$. tj. širina izla-znog otvora usipnog levka ispod drobilice je 1,5 m.

-Potrebna obodna sila na obodu pogonskog bubnja izračunava se iz izraza:

$$
\begin{aligned}
F_{b o}= & C \cdot t \cdot L \cdot g \cdot\left(G_{t}+\frac{Q_{h}}{3,6 \cdot V}\right)+ \\
+ & \frac{Q_{h} \cdot H}{3,6 \cdot V} d a N \\
\mathrm{C}- & \begin{array}{l}
\text { koeficijent koji uzima u obzir } \\
\text { povećanje vučne sile zbog spore- } \\
\text { dnih otpora duž transportera. } \\
\text { Zavisi od dužine transportera. }
\end{array}
\end{aligned}
$$


Za ovaj slučaj uzeće se vrednost 1,05 .

$\mathrm{L}(\mathrm{m})$ - dužina transportera.

$\mathrm{t}$ - koeficijent trenja $\mathrm{u}$ ležajevima (bubnjeva i valjaka). Za uslove povećane zaprašenosti uzima se vrednost 0,015 za rolne sa kugličnim ležajevima.

$\mathrm{g}\left(\mathrm{m} / \mathrm{s}^{2}\right)$ - ubrzanje zemljine teže.

$\mathrm{G}_{\mathrm{t}}(\mathrm{kg} / \mathrm{m})$ - masa pokretnih delova transportera po $1 \mathrm{~m} \mathrm{du}$ žine transportera.

$\mathrm{Q}_{\mathrm{h}}(\mathrm{t} / \mathrm{h})$ - masa transportovanog mateijala $\mathrm{ut} / \mathrm{h}$.

$\mathrm{v}(\mathrm{m} / \mathrm{s})$ - brzina gumene transportne trake.

$\mathrm{H}(\mathrm{m})$ - visina dizanja ili spuštanja tereta.

Tabela 2. Vrednosti parametara

\begin{tabular}{|c|c|}
\hline Parametar & \\
\hline $\mathrm{C}(/)$ & 1,05 \\
\hline $\mathrm{L}(\mathrm{m})$ & 25 \\
\hline $\mathrm{T}(/)$ & 0,015 \\
\hline $\mathrm{G}_{\mathrm{t}}(\mathrm{kg} / \mathrm{m})$ & 137,303 \\
\hline $\mathrm{Q}_{\mathrm{h}}(\mathrm{t} / \mathrm{h})$ & 2350 \\
\hline $\mathrm{H}(\mathrm{m})$ & 4,15 \\
\hline $\mathrm{v}(\mathrm{m} / \mathrm{s})$ & 2,47 \\
\hline $\mathrm{b}(\mathrm{m})$ & 2200 \\
\hline $\mathrm{F}_{\mathrm{bo}}$ & $3661 \mathrm{daN}$ \\
\hline
\end{tabular}

- Snaga na vratilu pogonskog bubnja se računa iz izraza:

$$
\begin{gathered}
P_{b o}=\frac{F_{b o} \cdot v}{102}, \\
P_{b o}=75 \mathrm{~kW}
\end{gathered}
$$

- Dodatna potrebna snaga usled čistača trake se računa iz izraza:

$$
P_{d}=1.6 \cdot b \cdot v \cdot n
$$

gde je:

$$
\mathrm{n} \text { - broj skidača }
$$

$$
P_{d}=1,6 \cdot 2,2 \cdot 2,47 \cdot 2=17 \mathrm{~kW}
$$

-Dodatna potrebna snaga usled bočnih vođica:

$$
P_{v}=0,08 \cdot 10 \mathrm{~m}=0,8 \mathrm{~kW}, \text { gde je: }
$$

- Efektivna snaga na vratilu pogonskog bubnja se računa iz izraza:

$$
\begin{gathered}
P_{e}=P_{b o}+P_{d}+P_{v}, \\
\mathrm{P}_{\mathrm{e}}=75+17+0,8=92,8 \mathrm{~kW}
\end{gathered}
$$

- Snaga pogonskog elektromotora se računa iz izraza:

$$
P_{e l}=\frac{P_{e}}{\eta}=\frac{P_{e}}{0,89 \cdot 0,95}
$$

gde je:

$\eta$-stepen stepen korisnosti dejstva

$$
\mathrm{P}_{\mathrm{el} .}=109,75 \mathrm{~kW}
$$

Usvajaja se električna snaga elektromotora od $110 \mathrm{~kW}$.

\section{ZAKLJUČAK}

Ovom analizom se dokazuje da trakasti dodavač sa postojećim elektromotorom snage $110 \mathrm{~kW}$, kao i postojećom gumenom trakom može da ispuni zahtevani kapacitet od $2350 \mathrm{t} / \mathrm{h}$. Interesantno u ovoj analizi je to, što sračunata snaga odgovara usvojenoj standardnoj snazi elektromotora, što je bitno za projektante u donošenju odluke oko izbora snage sletromotora. Prema ovoj analizi investotor je preuzeo sve potrebne aktivnosti da izvrši preseljenje postojećeg transportera sa lokacije rudnika Majdanpek i da uz dodatne modifikacije i repaparacije izvrši njegovu ugradnju na novoj lokaciji drobiličnog postrojenja br. 2 na površinskom kopu rudnika Veliki Krivelj. Nakon godine dana rada izgrađenog postrojenja, pokazalo se da je ova računska potvrda bila ispravna. 


\section{LITERATURA}

[1] „Tehnološke osnove projektovanja postrojenja za pripremu mineralnih sirovina“, Rudarski Institut Beograd, 1999.

[2] „Studija opravdanosti investiranja u proizvodnji kocentrata bakra na površinskom kopu i flotaciji ,Veliki Krivelj" - RTB Bor,“ Beograd, mart 2010 god. Geo-in International Beograd.

[3] „Dopunski rudarski projekat otkopavanja i prerade rude bakra u ležištu „Veliki Krivelj“" za kapacitet 10,6 x 10 tona vlažne rude godišnje. II. Tehnički projekti-Rudarski deo. II.3.Verifikacija kapaciteta i tehničko tehnološkog rešenja transportnog sistemamza jalovinu.
[4] „Dopunski rudarski projekat otkopavanja i prerade rude bakra u ležištu „Veliki Krivelj“ za kapacitet 10,6 x $10^{6}$ tona vlažne rude godišnje. III. Tehnički projekt-PMS deo. III. 1. Tehnički projekt prerade rude.

[5] R. Lekovski, R. Rajković, Lj. Obradović, Formiranje istočnog odlagališta jalovine u Boru i pregled dosadašnjih aktivnosti na zaštiti životne sredine, Rudarski radovi, 2 (2011), str. 125-130.

[6] D. Milanović, Z. Marković, D. Urosević, M. Ignjatović, Unapređenje sistema usitnjavanja rude u postrojenju „Veliki Krivelj“, Rudarski radovi, 1 (2011), str. 143-154. 


\begin{tabular}{ll}
\hline \hline MINING AND METALLURGY INSTITUTE BOR & YU ISSN: 1451-0162 \\
COMMITTEE OF UNDERGROUND EXPLOITATION OF THE MINERAL DEPOSITS & UDK: 622 \\
\hline \hline
\end{tabular}

UDK: $621.967 .2: 622 \cdot 27.1: 622.7(045)=20$

Bojan Drobnjaković, Dragan Milanović, Vesna Drobnjaković

\title{
SELECTION OF A BELT FEEDER DRIVE GROUP OF CRUSHING PLANT FOR ORE/WASTE AT THE OPEN PIT OF VELIKI KRIVELJ MINE *
}

\begin{abstract}
Construction of the primary crushing plant No. 2 within the open pit of the Veliki Krivelj mine has resulted in the increase copper ore processing capacity in order to increase the capacity of copper mine Veliki Krivelj from 8.0 to $10.5 \times 10^{6}$ tyear of ore [1,2]. An important and expensive technological position, within the facility, is the belt feeder below the primary crusher, type circular-conical Allis Chalmers 48" $x$ 74", which delivers ore further on a transport system for ore or transport system for waste, if the waste is crushed. With the capacity increase of ore/waste from the copper mine Veliki Krivelj, the quantity of overburden/ore is also increased of the same named open pit, and consequently the quantity of produced smelter slag from the process of copper concentrate smelting, obtained from the flotation plants Veliki Krivelj, Bor and Majdanpek.
\end{abstract}

Key words: transport system, ore/waste, belt feeder, drive group

\section{INTRODUCTION}

According to the adopted strategic plans for the development of RTB Bor, it is necessary to carry out the construction of crushing plant Plant No. 2 within the transport system for waste from the open pit of Veliki Krivelj mine to the excavated area of the open pit Bor. Futher considerations have resulted into an idea to use also this crushing plant for ore crushing, not only for waste crushing as it is the case with the existing crushing plant No. 1. The components of crushing plant are: receiving bin for ore/waste, products, sectional feeder, reception bin of crusher, circular conical primary crusher, output hopper of crusher, belt feeder under crusher, reloading chute, reversable feeder, output chute for ore anad output chute for waste. An integral part of crushing plant is a belt conveyor - feeder, which is located below crusher, and delivers the material on a reversible transporter for ore or transporter for waste. It is installed at angle of $5.5^{\circ}$.

\footnotetext{
* Mining and Metallurgy Institute Bor

${ }^{* *}$ This work is the result of the Project 33023 "Development of Flotation Processing Technologies of Copper Ore and Precious Metals to Achieve Better Technological Results", funded by the Ministry of Education and Science of the Republic of Serbia
} 
The investor has decided to use for this purpose the existing belt feeder from the Majdanpek mine, from so-called phase IV, which is out of operation for several years. Figure 1 gives a technological layout with component positions of installed crushing plant No. 2, while Figure 2 presents the constructed crushing plant No. 2, and Figures 3 and 4 present the the stages of installation the belt feeder drive group.

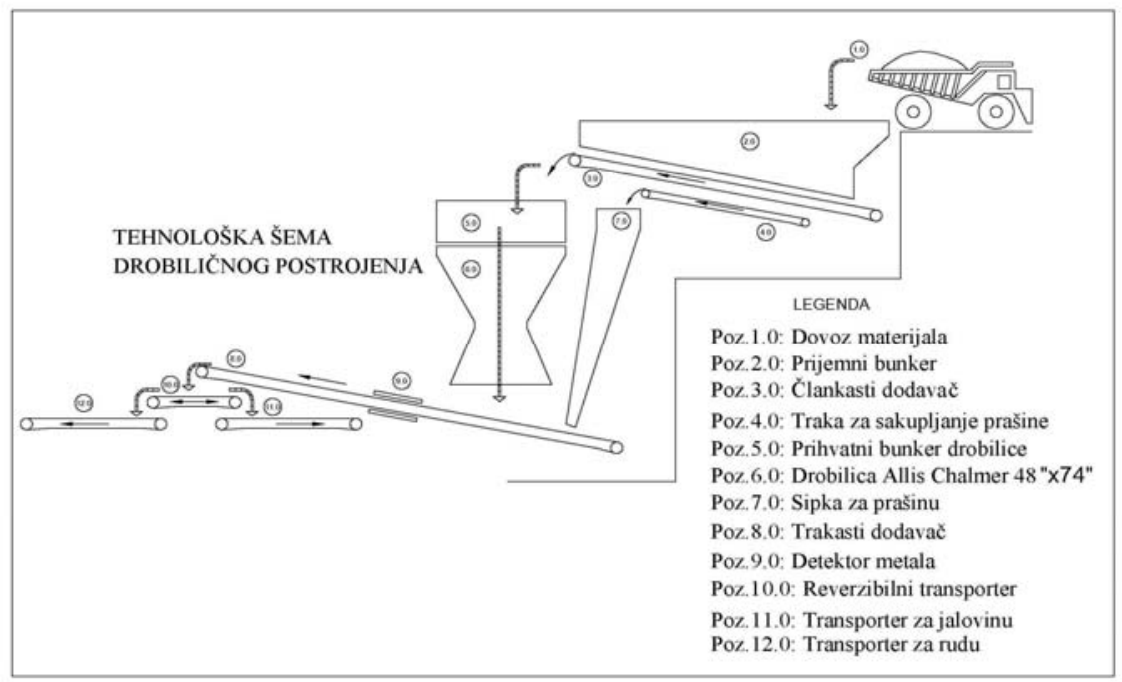

Fig. .1. Technological layout of installed crushing plant No. 2

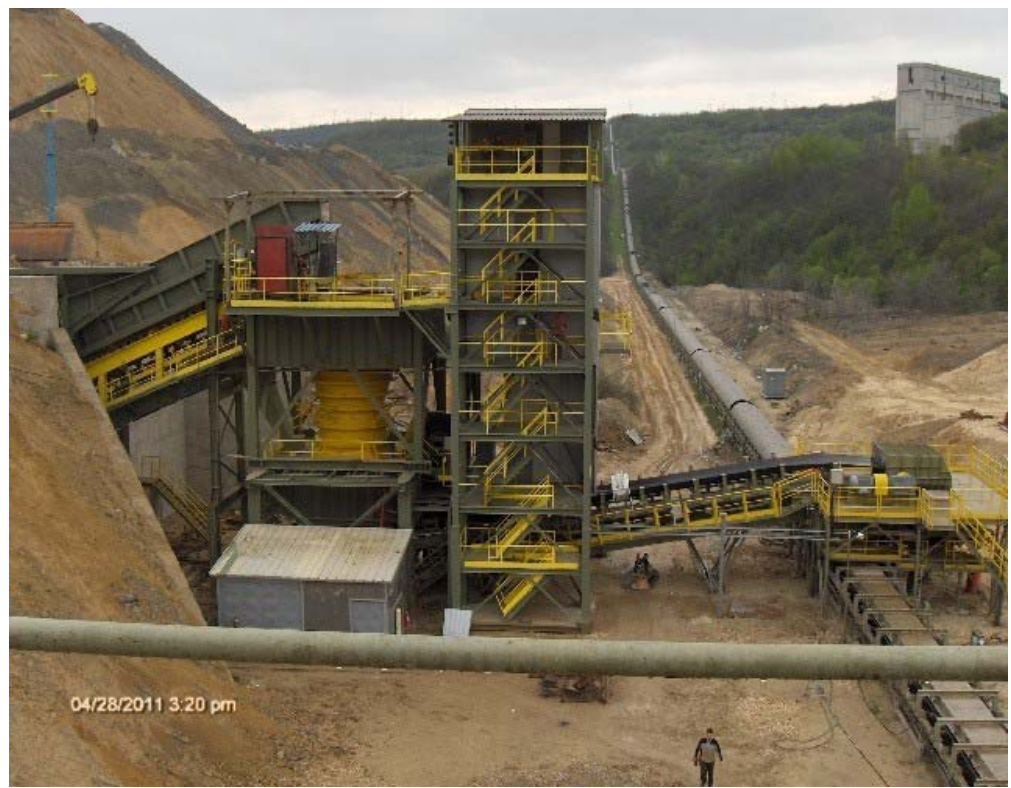

Fig. 2. Visual review of installed crushing plant No. 2 


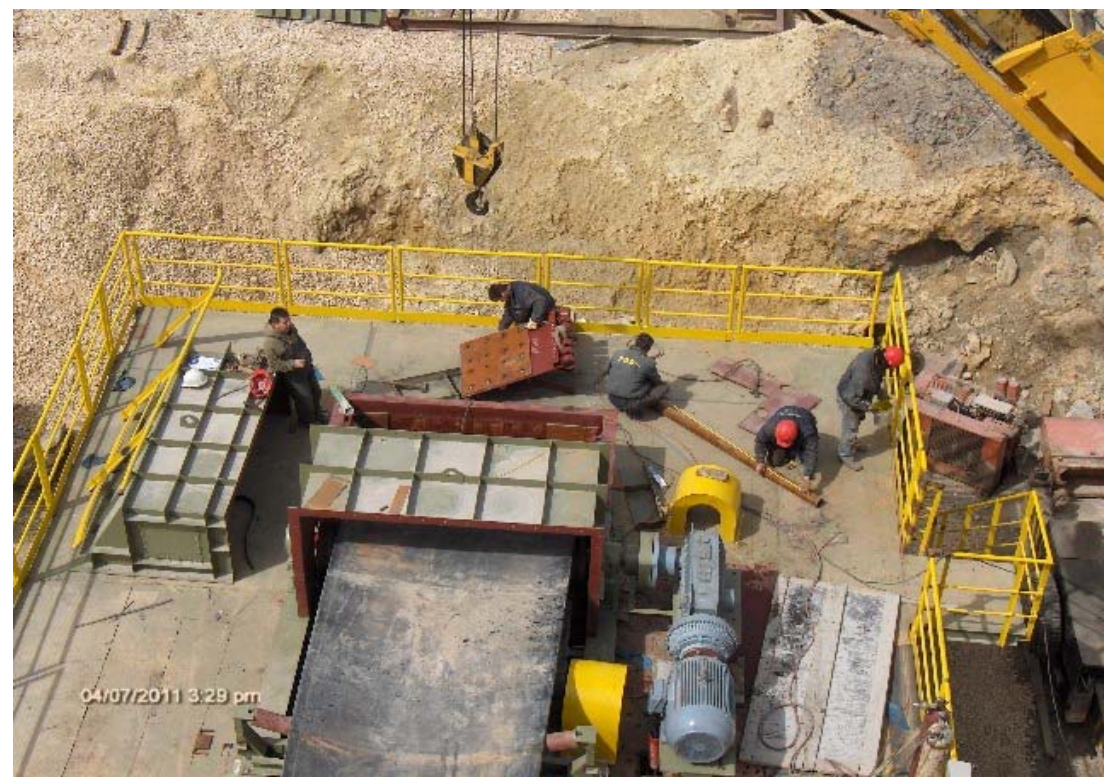

Fig. 3. Installation of belt feeder drive group position T-103.

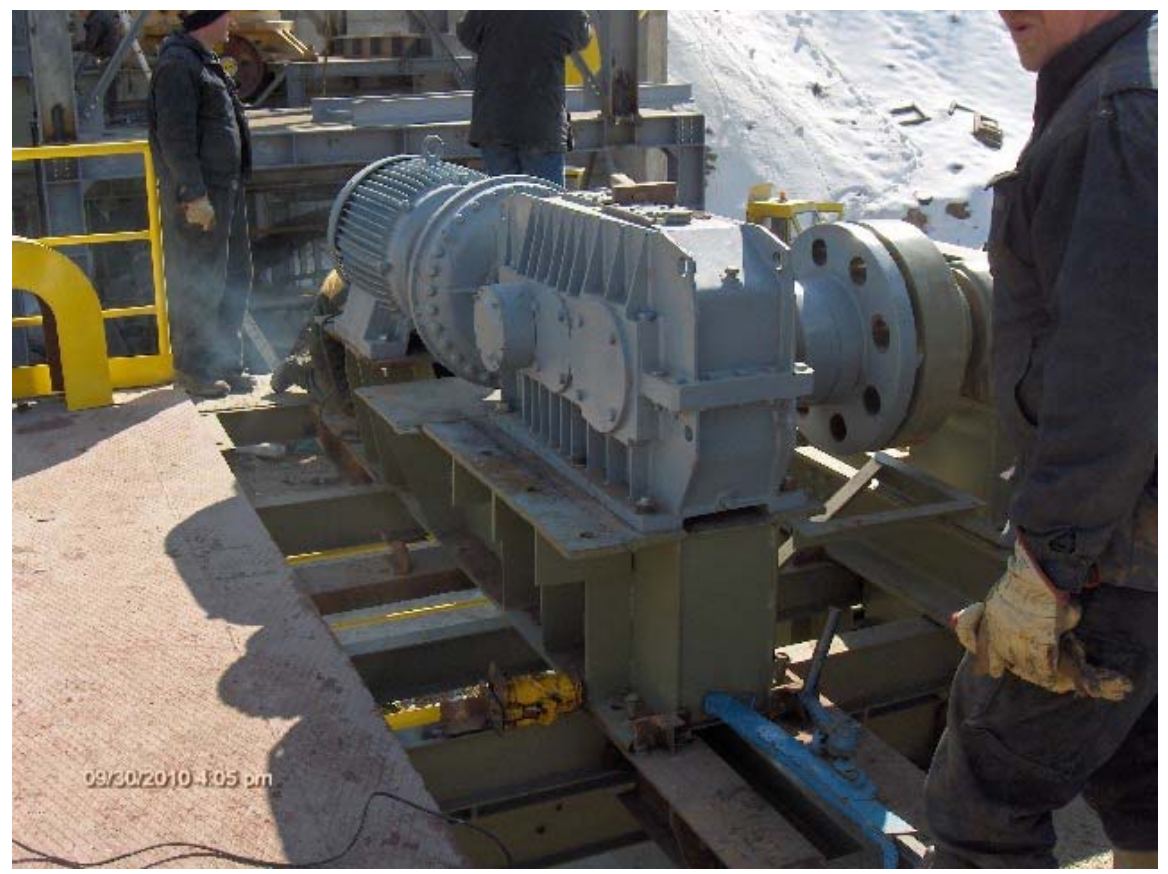

Fig. 4. Review of drive group - electric motor reducer of coupling 


\section{CALCULATION OF A CONVEYOR DRIVE GROUP T-103}

It is necessary to carry out an analysis of installed capacity of conveyorat position $\mathrm{T}-103$, thus checking the driving force of electric motor considering that a lifting height of transported material increases by $1.5 \mathrm{~m}$, which is not negligible $[3,4]$.

Whereas, it is expected that drive power of electric motor is in a limit of meeting the operational requirements. The amount of transported material is the same both at the position in the Majdanpek mine and at thisposition in the Veliki Krivelj mine.

Calculation of this belt conveyor can be made on the basis of the standard SRPS M.D2.050, due to a short length of conveyor.

Capacity calculation of the stationary belt conveyor means the verification of belt conveyor -feeder capacity under the primary crusher, technological positions of T-103, in a length of $25 \mathrm{~m}$ and lifting height of $4.15 \mathrm{~m}$ at a speed of rubber conveyor belt of $2.43 \mathrm{~m} / \mathrm{s}$.

\section{Selection of belt width}

Belt width is not determined by the capacity but by the crusher outlet. Width of rubber belt is $2200 \mathrm{~mm}$, and it satisfies in every way.

Checking a section of belt filling according to the quantity of transported material

A section of belt filling is calculated by the formula:

$$
A=\frac{1}{k_{1} \cdot k_{2}} \cdot \frac{Q}{3600 \cdot \rho \cdot v}
$$

where:

$$
\begin{aligned}
& \text { A - section area of filling, in } \mathrm{m}^{2}, \\
& \mathrm{Q} \text { - quantity (mass) of transported } \\
& \text { material, in } \mathrm{t} / \mathrm{h},
\end{aligned}
$$

$\rho$ - zapreminska masa (gustina) transportovanog materijala $\mathrm{u} \mathrm{kg} / \mathrm{m}^{3}$,

$\mathrm{v}$ - belt speed, $\mathrm{m} / \mathrm{s}$,

$\mathrm{k}_{1}$-coefficient of theoretical capacity reduction due to uneven and incomplete filling,

$\mathrm{k}_{2}$ - coefficient of theoretical capacity reduction due to conveyor slope,

Table 1.

\begin{tabular}{|c|r|}
\hline Parameter & \multicolumn{1}{|c|}{ T103 B } \\
\hline $\mathrm{Q}$ & $2350 \mathrm{t} / \mathrm{h}$ \\
\hline$\rho$ & $1600 \mathrm{~kg} / \mathrm{m}^{3}$ \\
\hline $\mathrm{k}_{1}$ & 0.95 \\
\hline $\mathrm{k}_{2}$ & 0.95 \\
\hline $\mathrm{v}$ & $2.1 \mathrm{~m} / \mathrm{s}$ \\
\hline $\mathrm{A}$ & $0.215 \mathrm{~m}^{2}$ \\
\hline
\end{tabular}

-Active belt width:

$$
b_{1}=\sqrt{\frac{A \cdot 3600}{f}}=1,2 \mathrm{~m}
$$

where:

$\mathrm{b}_{1}$ - active belt width, in $\mathrm{m}$

$\mathrm{f}$ - factor of filling section shape. For troughed shape, with lateral angles of $35^{\circ}$, the factor has a value, $\mathrm{f}=550$

Active belt width is $1.5 \mathrm{~m}$, i.e. the width of the chute outlet under the crusher is $1.5 \mathrm{~m}$.

-The required circumferential force on the edge of drive drum is calculated from the expression:

$$
\begin{aligned}
& F_{b o}= C \cdot t \cdot L \cdot g \cdot\left(G_{t}+\frac{Q_{h}}{3,6 \cdot V}\right)+ \\
&+\frac{Q_{h} \cdot H}{3,6 \cdot V} d a N \\
& \text { C - coefficient that takes into account } \\
& \text { the increase of traction due to } \\
& \text { side resistances along conveyor. }
\end{aligned}
$$


It depends on the length of conveyor. For this case, the value of 1.05 will be taken

L (m) - conveyor length

$\mathrm{t}$ - coefficient of friction in bearings (drums and rolls). For conditions of increased dust, the value of 0.015 will be taken for rolls with ball bearings takes the ball-bearing rollers.

$\mathrm{g}\left(\mathrm{m} / \mathrm{sec}^{2}\right)$ - gravity acceleration

$\mathrm{G}_{\mathrm{t}}(\mathrm{kg} / \mathrm{m})$ - mass of moving parts of conveyor per $1 \mathrm{~m}$ length of conveyor

$\mathrm{Q}_{\mathrm{h}}(\mathrm{t} / \mathrm{h})$ - weight of transported material in $t / h$

$\mathrm{v}(\mathrm{m} / \mathrm{s})$ - rubber conveyor belt speed

$\mathrm{H}(\mathrm{m})$ - height of lifting or lowering loads

Table 2. Parameter values

\begin{tabular}{|c|c|}
\hline Parameter & \\
\hline $\mathrm{C}(/)$ & 1.05 \\
\hline $\mathrm{L}(\mathrm{m})$ & 25 \\
\hline $\mathrm{T}(/)$ & 0.015 \\
\hline $\mathrm{G}_{\mathrm{t}}(\mathrm{kg} / \mathrm{m})$ & 137.303 \\
\hline $\mathrm{Q}_{\mathrm{h}}(\mathrm{t} / \mathrm{h})$ & 2350 \\
\hline $\mathrm{H}(\mathrm{m})$ & 4.15 \\
\hline $\mathrm{v}(\mathrm{m} / \mathrm{s})$ & 2.47 \\
\hline $\mathrm{b}(\mathrm{m})$ & 2200 \\
\hline $\mathrm{F}_{\mathrm{bo}}$ & $3661 \mathrm{daN}$ \\
\hline
\end{tabular}

- Power on a shaft of drive drum is calculated from the expression:

$$
\begin{gathered}
P_{b o}=\frac{F_{b o} \cdot v}{102}, \\
P_{b o}=75 \mathrm{~kW}
\end{gathered}
$$

- Additional required power due to the belt cleanera is calculated from the expression:

$$
P_{d}=1.6 \cdot b \cdot v \cdot n
$$

where:

$\mathrm{n}$ - number of scrapers

$$
P_{d}=1,6 \cdot 2,2 \cdot 2,47 \cdot 2=17 \mathrm{~kW}
$$

- Additional required power due to the lateral guides:

$$
P_{v}=0,08 \cdot 10 \mathrm{~m}=0,8 \mathrm{~kW}
$$

where:

- Effective power on a shaft of drive drum is calculated from the expression:

$$
\begin{gathered}
P_{e}=P_{b o}+P_{d}+P_{v}, \\
P_{e}=75+17+0,8=92,8 \mathrm{~kW}
\end{gathered}
$$

- Power of drive electric motor is calculated from the expression:

$$
P_{e l}=\frac{P_{e}}{\eta}=\frac{P_{e}}{0,89 \cdot 0,95}
$$

where:

$\eta$ - degree of efficiency

$$
P_{e l .}=109.75 \mathrm{~kW}
$$

Electric motor power of $110 \mathrm{~kW}$ is adopted.

\section{CONCLUSION}

This analysis has confirmed that the belt feeder with the existing electric motor, power of $110 \mathrm{~kW}$, and the existing rubber belt, can not meet the required capacity of $2350 \mathrm{t} / \mathrm{h}$. Interestingly, it is in this analysis that the calculated power corresponds to the adopted standard power of electric motor, what is important for designers in making decisions about selection of electric motor power. According to this analysis, the investor has taken all necessary activities to carry out the relocation of the existing conveyor from the Majdanpek mine location, and with additional modifications and reparations to install it at the new location of crushing plant No. 2, at the open pit of Veliki Krivelj mine. After a year of constructed facility, it was shown that this computational confirmation was correct. 


\section{REFERENCES}

[1] Technological Basis of the Plant Design for Mineral Processing, Mining Institute, Belgrade, 1999 (in Serbian);

[2] Feasibility Study of Investment in Copper Concentrate Production at the Open Pit and Flotation Plant Veliki Krivelj - RTB Bor, Belgrade, March 2010, Geo-International, Belgrade (in Serbian);

[3] Additional Mining Project of Copper Ore Mining and Processing in the Deposit Veliki Krivelj for the Capacity of $10.6 \times 10^{6}$ Tons of Wet Ore per Annualy, II.Technical Projects-Mining Part, II.3. Verification of Capacity and Technical-Technological Solution of Transport System for Waste, Archives of Mineral Processing Department, Mining and Metallurgy Institute Bor (in Serbian);

[4] Additional Mining Project of Copper Ore Mining and Processing in the Deposit Veliki Krivelj for the Capacity of $10.6 \times 10^{6}$ Tons of Wet Ore per Annualy, II.Technical Project-Mineral Processing Part, II.3. Verification of Capacity and Technical-Technological Solution of Transport System for Waste, Archives of Mineral Processing Department, Mining and Metallurgy Institute Bor (in Serbian).
[5] R. Lekovski, R. Rajković, Lj. Obradović, Formation of the East Waste Dump in Bor and Review of Previous Activities on the Environmental Protection, Mining Engineering, 2 (2011), pp. 131-136.

[6] D. Milanović, Z. Marković, D. Urosević, M. Ignjatović, System Improvement of ore Comminuting in Veliki Krivelj Plant, Mining Engineering, 1 (2011), pp. 155-166. 